\title{
TEMPERATURE AND SOME BLOOD TRAITS RESPONSE TO ORGANIC AND INORGANIC SELENIUM ADDED TO THE BROILER DIET REARED AT HIGH TEMPERATURES
}

\author{
N. K. Ali \\ Researcher \\ D. H. Al-Hassani \\ Prof. \\ Dept. Animal Prod - Coll Engin Sci University of Baghdad \\ nahla.kadhem.ali@gmail.com \\ alhassani.dihya@yahoo.com
}

\begin{abstract}
This study was conducted at the poultry farm -Animal Production Department/ College of Agricultural Engineering Sciences- University of Baghdad, for the period from 2018/8/17 to 2018/9/28, in order to study the effect of adding inorganic and organic selenium to the broiler diets reared at high temperatures in the physiological performance. A 420 un-sexed chicks of breed (Ross 308) were used in the experiment as a one-day old and with weight rate of $36.4 \mathrm{~g}$. The chicks were distributed randomly and equally on 7 treatments, each one included 3 replicates at 20 chicks/replicate. The experiment included the following treatments : T1,T2, and T3 as organic selenium treatments which are selenomethionin with a concentration of $0.3,0.6$, and $0.9 \mathrm{mg} / \mathrm{kg}$ feed, respectively, and T4, T5, and T6 as inorganic selenium treatments in the form of Sodium Selenite compound at a concentrations of $0.3,0.6$, and $0.9 \mathrm{mg} / \mathrm{kg}$ feed, respectively, and $\mathrm{T} 7$ control treatment without any addition of selenium, while the chicks were bred at a high temperature rate of $22.5-43.9{ }^{\circ} \mathrm{C}$. Organic and inorganic Selenium have not shown a clear effect in reducing body temperature compared to the control treatment, as well as, a high significant decreasing in the blood Hematocrit and Hemoglobin concentration for inorganic Selenium treatments compared to the organic Selenium and control treatments. Finally, The results indicated that there were no significant differences in the cholesterol and glucose levels in blood of organic and inorganic Selenium and control treatments.
\end{abstract}

Keywords: heat stress, cholesterol, body temperature

Part of M.Sc. thesis for the $1^{\text {st }}$ author

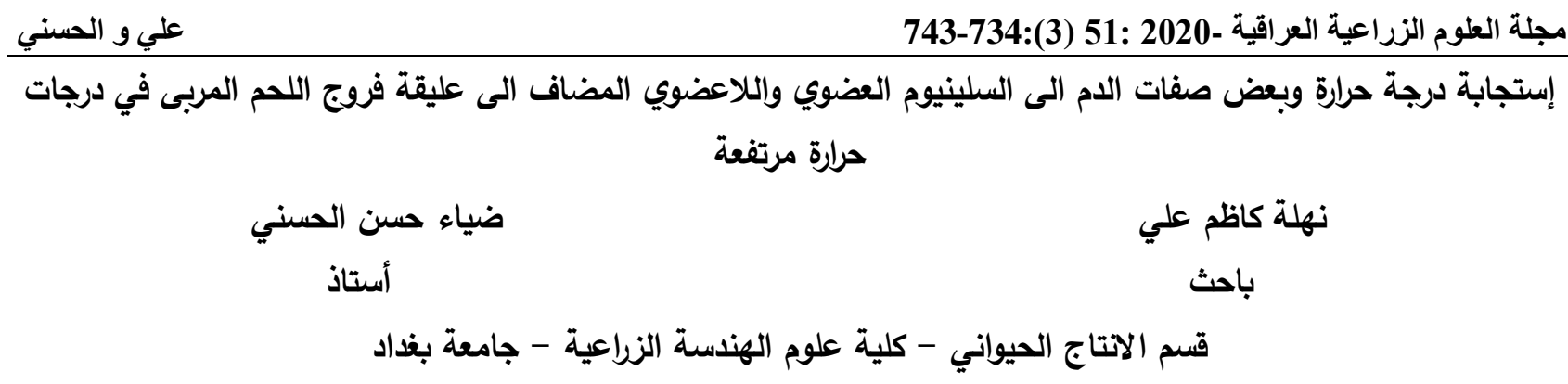

أجريت هذه الدراسة في حقل الطيور الداجنة, قسم الاتتاج الحيواني, كلية علوم الهندسة الزراعية جامعة بغداد للمدة من

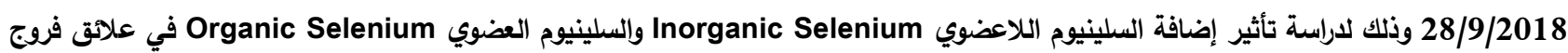
اللحم المربى في درجات الحرارة المرتفعة في الأداء الفسلجي. استخدم في التجربة 420 فرخ لحم غير مجنس سلالة (308 Ross) عند عمر يوم

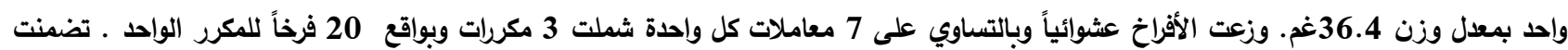

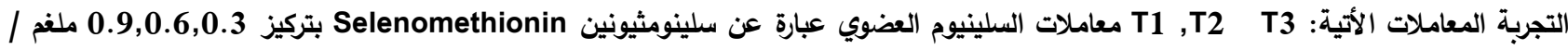
كفم علف على التوالي و Sodium Selenite معاملات السلينيوم اللاعضوي على هيئة مركب صوديوم سلينيت T6, T5 ,T4 بتركيز

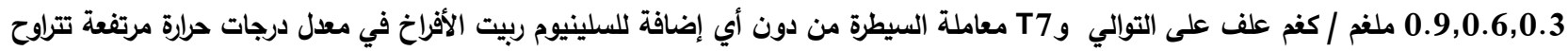

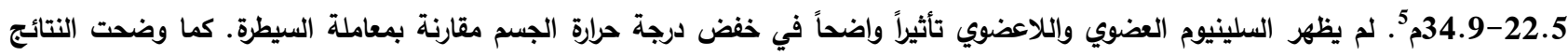
حصول انخفاضاً معنوياً عالياً في مكداس الدم وتركيز الهيموكلوبين في الام لمعاملات السلينيوم اللاعضوي مقارنة بمعاملات السلينيوم العضوي والسيطرة. وأثارت النتائج الى عدم وجود فروق معنوية في مستوى الكولسترول والكلوكوز في الدام لمعاملات السلينيوم العضوي واللاعضوي ومعاملة 


\section{INTRODUCTION}

Poultry rearing is directly affected by climatic conditions, especially temperature and humidity. Iraq's climate is characterized by high temperatures in most days of the year that affecting poultry performance, as the consumption of feed decreases and causes a reduction in the availability of some essential nutrients $(9,15)$, which negative effects on the growth rate $(2,25)$, As well as, food conversion efficiency $(7,24)$, and the meat quality, eggs and fertility which caused major economic losses (30). The modern breeds of broiler are characterized by fast growth and excellent food conversion efficiency that are sensitive to high temperatures, making them more susceptible to heat stress (16). The researchers applied several procedures in genetics $(3,1)$, and nutrition $(4,8,10,26)$ and rearing $(5,6)$ in an attempt to overcome this problem. Many studies have indicated that the heat stress leads to oxidative stress as heat stress reduces the antioxidant role, which is one of the most important physiological changes in response to high temperatures and thus increases the oxidation state that affects the birds immune response (36, 37). Antioxidants such as Selenium were used to remove the effect of free radicals, where the using of antioxidants in feed provides a protection for the feed from oxidation during storage as well as, its role in interacting with free radicals formed. Thus, prevents oxidation of unsaturated fatty acids in the cells and tissues of the body (19). Selenium is found in several forms of organic, inorganic and NanoSelenium, which varies in the absorption, efficiency, and metabolism mechanisms, researches indicates that organic Selenium has similar efficiency to Nano-Selenium compared to inorganic Selenium (27). Common sources of Selenium supplementation are Sodium Selenite, Selenium yeast, Selenomethionin and Nano-Selenium, where (48) indicated that organic sources are more effective than inorganic sources. Selenium is one of the most essential trace elements, which is involved in many of the physiological functions in the bird body. The most important of which is the antioxidant action, which is one of the essential components of the Glutathione peroxidase enzyme found in most of the body's tissues (11). It has been found that giving Selenium improves thyroid function ( 22 ), and plays an important role in breaking down free radicals that attack the cell membrane and plasma lipoproteins (35). Selenium supplementation has also been shown to enhance the performance and antioxidant activity of broiler during heat stress ( 34, 43 ). Furthermore, Selenium is important in improving the qualitative, quality, validity of poultry meat through its antioxidant capacity $(40,46)$. It provides also a protection for the cell by interacting with peroxide roots, the use of Selenium as additives in feed improves the healthy and productive performance of the animal and increases the content of Selenium in meat and eggs (23). The main advantage of Selenium is its ability to build a reserve in the body as a Selenomethionin, which can be used when it's level decreases and enhances body defenses (42), while the level that poultry needed in the diet during growth period of broiler in optimum conditions it is $0.15 \mathrm{ppm}$ (29). The levels of Selenium added to poultry have varied depending on the variation of environmental conditions such as high temperatures, bird species, age and production status, as well as the level of Selenium in the diet components. Several studies and research have also been carried out in the establishment the optimal levels of Selenium component in the various poultry diets, but at the same time, it is recorded there is a considerable shortage and conflict in the study results on the role of the Selenium in reducing the adverse effects of heat stress, especially on the physical qualities and broiler production efficiency reared under a condition of heat stress. Therefore, this study was aimed to using different sources and levels of Selenium added to the broiler diet, reared under high temperatures and its effect on some blood characteristics and body temperature that providing us the physiological condition of birds.

\section{MATERIALS AND METHODS}

The experiment was conducted at the poultry farm/Animal Production Department /College of Agricultural Engineering Sciences / University of Baghdad - Abu Ghraib, for the period from $2018 / 8 / 17$ to $2018 / 9 / 28$. The chicks were reared in a closed house type divided by pens-shaped with three air 
ventilators to move the air across the house. A 420 one day old un-sexed Ross 308 broiler chicks, $36.4 \mathrm{~g}$ average weight were purchased from private hatchery distributed randomly inside the pens to seven treatments with 60 chicks/treatment, each treatment included 3 replicates, 20 chicks / replicate. The birds were reared in a continuous heat stress conditions, where water and food were provided freely (Ad-Libitum). The air cooler, as well as, a vertical fan was used for the lowering the very high house temperature and a continuous lighting system, 23 hour light/1 hour dark daily was used. Two sources of Selenium, including inorganic Selenium in a form of Sodium Selenite and its chemical formulation $\mathrm{Na}_{2} \mathrm{Se}_{3}$, a British origin with a molecular weight of 172.94 , and a purity $99.9 \%$ in the form of white Powder, while the organic Selenium was a Selenomethionin of Zinpro products. Moreover, the feed was produced by crush and mixing of the dietary ingredients according to the required proportions in the feed plant of the Animal Production Department / College of Agricultural Engineering Sciences / University of Baghdad. Selenium was added according to its proportions in the various treatments diets, where the starter diet provided to the chicks during the first 10 days of age, then it was gradually replaced by a grower diet from the age of 11 to 24 days, then replaced by the finisher diet from the age of 25 to the marketing age 42 days (Table 1). The nutritional treatments have been divided as follows: The first treatment contained organic Selenium with a concentration of $0.3 \mathrm{mg} / \mathrm{Kg}$ diet, the second treatment contained organic Selenium with a concentration of $0.6 \mathrm{mg} / \mathrm{kg}$ diet, and the third treatment contained organic Selenium with a concentration of $0.9 \mathrm{mg} / \mathrm{kg}$ diet. Furthermore, the fourth treatment contained inorganic Selenium with a concentration $0.3 \mathrm{mg} / \mathrm{kg}$ diet, while the fifth treatment contained inorganic Selenium with a concentration of $0.6 \mathrm{mg} / \mathrm{kg}$ diet, and the sixth treatment contained inorganic Selenium with a concentration of $0.9 \mathrm{mg} / \mathrm{kg}$ diet, and the seventh treatment was the control diet, which represents the basal diet without adding Selenium. The house temperature and relative humidity was recorded hourly ( Fig 1 ) by using an electronic device (TCH-4), manufactured by Restriction of Hazardous Substances (ROHS) Chinese origin . Bird body temperature was measured at 6 am, 12 $\mathrm{pm}$, and $6 \mathrm{pm}$ by measuring the rectal temperature of 5 birds of each replicate, birds whose temperature was measured has been marked in each replicate and for weeks ( 3, 4, $5)$. 
Table 1. Composition and calculated chemical analysis of experimental diets for starter, grower and finisher phases.

\begin{tabular}{|c|c|c|c|}
\hline Feed material & $\begin{array}{c}\text { Starter diet } \\
\text { (1-10) day }\end{array}$ & $\begin{array}{l}\text { Grower diet } \\
(11-24) \text { day }\end{array}$ & $\begin{array}{l}\text { Finisher diet } \\
(25-42) \text { day }\end{array}$ \\
\hline Yellow maize & 45.8 & 47.2 & 49.7 \\
\hline Local wheat & 10 & 11.3 & 11.1 \\
\hline Soybean meal $(48 \%)$ & 34.3 & 30.6 & 27.1 \\
\hline Protein concentrate $^{(1)}$ & 5 & 5 & 5 \\
\hline Sunflower oil & 2.6 & 3.7 & 4.9 \\
\hline Limestone & 1.1 & 1.1 & 1.1 \\
\hline Dicalcium phosphate (DCP) & 0.7 & 0.6 & 0.6 \\
\hline Salt & 0.3 & 0.3 & 0.3 \\
\hline Mixture of Vitamin and Mineral ${ }^{(2)}$ & 0.2 & 0.2 & 0.2 \\
\hline \begin{tabular}{|c|} 
Total \\
\end{tabular} & 100 & 100 & 100 \\
\hline \multicolumn{4}{|c|}{ Calculated Chemical Analysis ${ }^{(3)}$} \\
\hline Crude protein $(\%)$ & 23.00 & 21.5 & 20.00 \\
\hline $\begin{array}{l}\text { Calculat metabolism energy } \\
\text { (kcal/kg feed) }\end{array}$ & 3004.25 & 3100.43 & 3200.5 \\
\hline Lysine $(\%)$ & 1.35 & 1.25 & 1.16 \\
\hline Methionine (\%) & 0.512 & 0.49 & 0.47 \\
\hline Cysteine\% & 0.373 & 0.35 & 0.33 \\
\hline Methionine+ Cysteine (\%) & 0.885 & 0.84 & 0.80 \\
\hline Calcium \% & 1.02 & 0.99 & 0.98 \\
\hline Available p\% & $\mathbf{0 . 5 0}$ & 0.48 & 0.47 \\
\hline
\end{tabular}

(1) The protein concentrate ( WAFI) type BROC0N-5Jebur, manufactured in the Netherlands, each kg contains:30\% crude protein, $3.50 \%$ crude fat , $4.86 \%$ crude fiber, $6.81 \%$ Ca, $2.65 \%$ phosphorus $5.34 \%$ available phosphorus, $3.85 \%$ Lysine, $3.70 \%$ Methionine, $4.06 \%$ Methionine+ Cysteine, $2.40 \%$ Na, 174068 (Kcal/Kg feed) metabolism energy, also including vitamin A 200000IU, vitamin D3 80000IU, vitamin E 600Mg, vitamin K3 $50 \mathrm{mg}$, vitamin B1 $60 \mathrm{mg}$, vitamin B2 $140 \mathrm{mg}$, vitamin B6 $80 \mathrm{mg}$, vitamin B12 $700 \mathrm{mg}$, folic acid $20 \mathrm{mg}$, Niacin $800 \mathrm{mg}$, Butane $2 \mathrm{mg}$, iron1000 mg, copper $200 \mathrm{mg}$, manganese 1600mg, zinc $1200 \mathrm{mg}$, Iodine $20 \mathrm{mg}$, Selenium $5 \mathrm{mg}$, antioxidants $33.50 \%$ (BHT).

(2) The vitamin and mineral mixture of colavita, each kg contains: 500 IU Vitamin A, 600 IU D3,10 mg E, 2mg K3,2 mg B1, 2 mg B2,2 mg B6, 5mg B12, $10 \mathrm{mg} \mathrm{C}, 15 \mathrm{mg}$ Niacin, $500 \mathrm{mg}$ folic acid, $4.8 \mathrm{mg}$ calcium, $3.18 \mathrm{mg} \mathrm{p,} 10 \mathrm{mg}$ copper, $80 \mathrm{mg}$ manganese, $80 \mathrm{mg}$ zinc, $50 \mathrm{mg}$ iron, $0.2 \mathrm{mg}$ selenium, $0.1 \mathrm{mg}$ cobalt, $0.5 \mathrm{mg}$ Iodine, $100 \mathrm{mg}$ antioxidants.

(3) Calculated Chemical Analysis of the diet according to NRC (1994).

A sensitive digital thermometer for one decimal point was used by inserting the thermoprobe of the thermometer through the Cloaca vent inside the rectum for $6 \mathrm{~cm}$ and until the reading stabilizes, and record the temperature, then take the reading average ( 47 ). Blood was collected from birds for each treatment (4 of each sex) at 25, and 42 days of age from the brachial vein, where the blood was discharged directly into two types of tubes, the first tubes contain on an antithrombotic potassium-Ethylene (Diamin Tetra Acid K-EDTA), used to measure the packed cell volume (PCV) and the hemoglobin $(\mathrm{Hb})$. The second was a tubes contain on a gel with a capacity of $6 \mathrm{ml}$, where placed in the centrifuge at $4000 \mathrm{rpm}$ for 10 minutes for the separating serum then its keept at $\left(-20^{\circ} \mathrm{C}\right)$ until tests are carried out. (PCV) estimated as ( 13 ) pointed out, and $(\mathrm{Hb})$ was calculated based on the equation that mentioned by ( 17 ). Finally, the glucose was estimated by using a Kit test tool manufactured by a Spanish company called Linear Chemicals.S.L. The cholesterol test was performed using a Kit test tool manufactured by the same company mentioned previously. The experiment data were analyzed using Complete Randomized Design (CRD) to determine the effect of treatments in the studied traits, then the significant differences were compared between averages with the multiple range test ( 20 ) and used statistical analysis system ( 38 ).

\section{RESULTS AND DISCUSSION}

Figure 1 illustrates the average temperature and humidity inside the rearing house being recorded hourly in each day of the experiment. The figure shows that birds were exposed to high temperatures, where the highest temperature recorded $43.9^{\circ} \mathrm{C}$ at $3 \mathrm{pm}$ and the lowest temperature of $22.5{ }^{\circ} \mathrm{C}$ at $6 \mathrm{am}$, and the highest average temperature was between 1-5 pm, while the high humidity was recorded $55.3 \%$ at 7 am and the lowest level was $19.6 \%$ 
at 5:00 pm, and the highest average humidity was between 9-4 am, these indicate that the birds have been subjected to severe heat stress was consistent with the aim of the experiment. The optimum house temperature for broiler chicken is $25-20^{\circ} \mathrm{C}$, so when it rise over $30^{\circ} \mathrm{C}$, it causes several problems for broiler (2). El Boushy and Van Marie (21) observed that the temperatures between $25-15{ }^{\circ} \mathrm{C}$ and humidity $65-60 \%$ is an ideal condition for broiler chicken. During the duration of the experiment, the humidity was not high, which helped to dissipate the high heat, as high temperatures accompanied by high humidity are dangerous and can kill birds. ( 32 ) indicated that during heat stress, a large part of the birds body's heat is dissipated by evaporation, which may be a hindrance if the humidity is high.

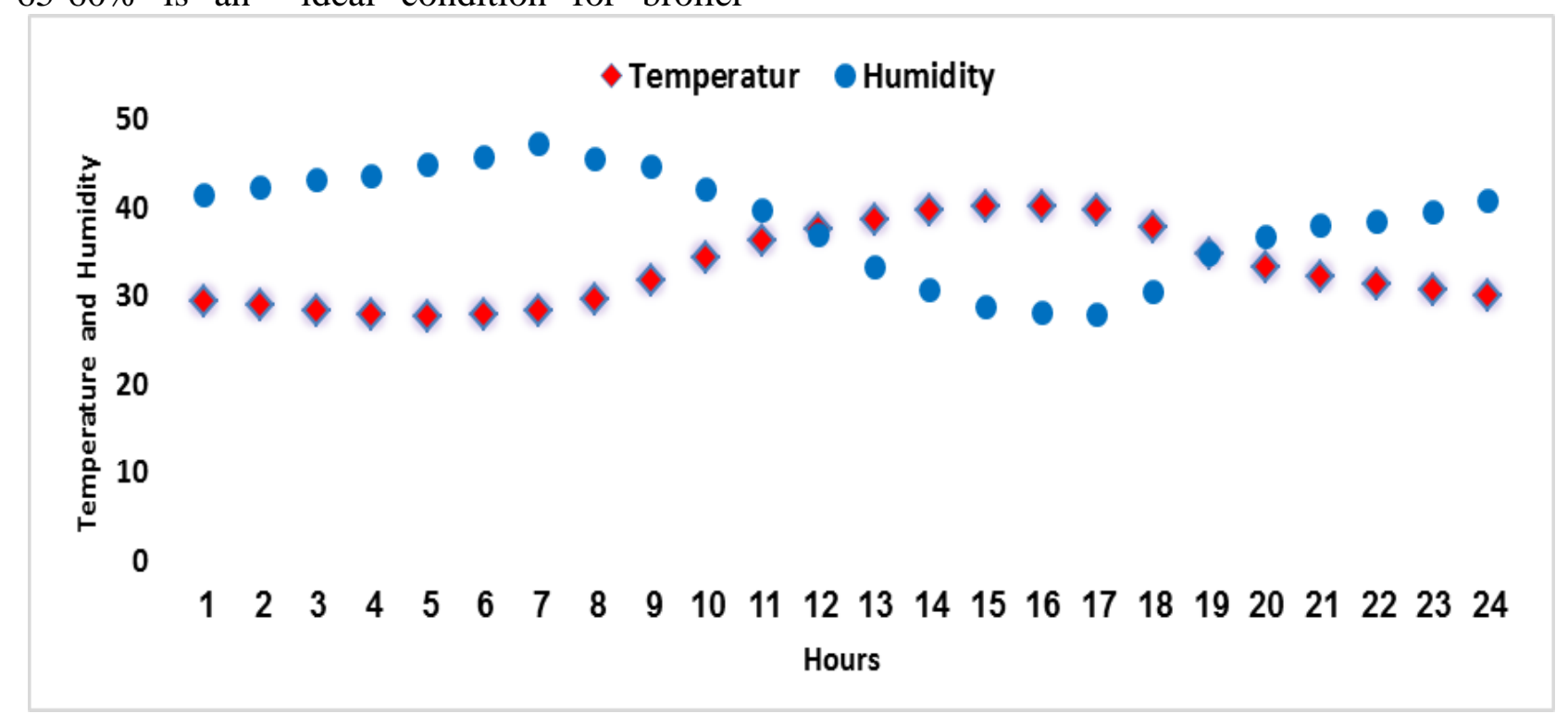

Figure 1.The average temperature and humidity for 24 hours throughout the experiment

Table 2 exhibited a significant decrease in body temperature at the $3^{\text {rd }}$ week of age in treatments T3, T5, T6 and T7 compared to the treatment $\mathrm{T} 1$, which did not differ significantly from T2 and T4 at 6.00 hour, while there was a high significant decrease in body temperature of 12.00 for T5 and T6 compared to the rest of the treatments. Furthermore, a significant decrease in treatment T6 compared to the T5 and T7 treatments at 18.00 hour. Results of $4^{\text {th }}$ week showed a significant decrease in body temperature in T5 and T6 compared to the rest of the treatments at 6.00 hour. The body temperature in $\mathrm{T} 6$ decreased compared to the rest of the treatments at 12.00 hour. At 18.00 hour there was a significant decrease in body temperature in T5 compared to other treatments. Table 2 also shows no significant differences in the body temperature in the $5^{\text {th }}$ week of age at 6.00 and 12.00 hour, while there were a significant differences at 18.00 hour, where the body temperature decreased in the control treatment, T2 and T4 compared to other treatments. Statistical analysis showed a variation in birds body temperature at 3, 4, and 5 weeks of age which was due to the variation of house temperature, since the organic and inorganic Selenium levels did not have a clear effect in lowering body temperature. The data generally indicate that the body temperature rises as the temperature of poultry house increases, while the lowest body temperature was coinciding with lowest house temperature of the day $(6.00$ am). (12) indicated that the increasing of the environment temperature by one degree Celsius leads to a rise in a bird's body temperature at a range of $0.121^{\circ} \mathrm{C}$. As well as, $(2,45)$ also pointed out that when the broiler exposed to a high temperature at an early age, it reduces body temperature and improves the long-term broiler resistance to heat stress. The results of the study are consistent with what (28) stated, where the different sources of Selenium (organic, inorganic and Nano Selenium) did not have aclear effect on rectal temperature. 
Table 2. Effect of adding different levels of organic Selenium (Selenomethionin) and inorganic (sodium selenite) to the diet in the body temperature for the weeks $(3,4,5)$ of broiler age rearing at a high temperatures (general average \pm standard error).

\begin{tabular}{|c|c|c|c|c|c|c|c|c|c|}
\hline \multirow[t]{3}{*}{ Treatments } & \multicolumn{8}{|c|}{ Hours } & \\
\hline & \multicolumn{3}{|c|}{$3^{\text {rd }}$ week } & \multicolumn{3}{|c|}{$4^{\text {rd }}$ week } & \multicolumn{3}{|c|}{$5^{\text {rd }}$ week } \\
\hline & 6.00 & 12.00 & 18.00 & 6.00 & 12.00 & 18.00 & 6.00 & 12.00 & 18.00 \\
\hline T1 & $41.61 \pm^{A} 0.12$ & $42.43 \pm^{A} 0.11$ & $42.37 \pm^{A} 0.05$ & $41.45 \pm{ }^{A} 0.14$ & 42.09 $\pm{ }^{\mathrm{A}} \mathbf{0 . 1 1}$ & 41.77 $\pm{ }^{\mathrm{A}} \mathbf{0 . 0 7}$ & $41.47 \pm 0.08$ & $42.24 \pm 0.07$ & $41.80 \pm^{\mathrm{AB}} 0.09$ \\
\hline $\mathbf{T 2}$ & $41.36 \pm^{\mathrm{AB}} 0.07$ & 42.37 $\pm^{A} 0.17$ & $42.42 \pm{ }^{A} 0.11$ & $41.29 \pm^{\mathrm{ABC}} 0.09$ & 42.07 $\pm{ }^{A} \mathbf{0 . 0 9}$ & $41.73 \pm{ }^{A} 0.13$ & $41.33 \pm 0.05$ & $42.27 \pm 0.08$ & $41.63 \pm{ }^{B} 0.08$ \\
\hline $\mathbf{T 3}$ & $41.13 \pm{ }^{B} 0.10$ & 42.19 $\pm{ }^{A} 0.11$ & $42.45 \pm{ }^{\mathrm{A}} 0.06$ & $41.00 \pm^{\mathrm{CD}} 0.11$ & $41.93 \pm \pm^{\mathrm{AB}} 0.06$ & $41.54 \pm^{\mathrm{AB}} 0.09$ & $41.21 \pm 0.08$ & $42.13 \pm 0.07$ & $41.73 \pm^{\mathrm{AB}} 0.05$ \\
\hline $\mathbf{T 4}$ & $41.36 \pm^{\mathrm{AB}} 0.10$ & $42.18 \pm{ }^{A} 0.10$ & $42.37 \pm{ }^{A} 0.09$ & $41.06 \pm^{\mathrm{BCD}} 0.08$ & $41.88 \pm^{\mathrm{AB}} 0.08$ & $41.55 \pm^{\mathrm{AB}} 0.17$ & 41.33 \pm 0.07 & $42.05 \pm 0.06$ & $41.71 \pm{ }^{B} 0.07$ \\
\hline T5 & $41.03 \pm{ }^{B} 0.12$ & $41.79 \pm{ }^{B} 0.09$ & $41.97 \pm{ }^{B} 0.12$ & $40.75 \pm^{\mathrm{D}} 0.10$ & $41.91 \pm^{\mathrm{AB}} 0.05$ & $41.33 \pm{ }^{B} 0.12$ & $41.29 \pm 0.08$ & $42.21 \pm 0.06$ & $41.80 \pm^{\mathrm{AB}} 0.07$ \\
\hline T6 & $41.13 \pm^{\mathrm{B}} 0.14$ & $41.65 \pm{ }^{B} 0.13$ & $41.70 \pm{ }^{C} 0.07$ & $40.81 \pm{ }^{D} 0.11$ & $41.67 \pm{ }^{B} 0.09$ & $41.45 \pm^{\mathrm{AB}} 0.06$ & $41.48 \pm 0.10$ & $42.11 \pm 0.11$ & $41.77 \pm^{\mathrm{AB}} 0.06$ \\
\hline $\mathbf{T 7}$ & $41.23 \pm{ }^{B} 0.09$ & 42.47 $\pm{ }^{\mathrm{A}} \mathbf{0 . 0 7}$ & 42.49 $\pm{ }^{\mathrm{A}} 0.05$ & $41.37 \pm{ }^{\mathrm{AB}} \mathbf{0 . 1 0}$ & 42.08 $\pm{ }^{\mathrm{A}} 0.12$ & $41.71 \pm{ }^{A} 0.05$ & $41.21 \pm 0.12$ & $42.14 \pm 0.06$ & $41.93 \pm^{A} 0.06$ \\
\hline Significant level & 0.05 & 0.01 & 0.01 & 0.01 & 0.01 & 0.05 & N.S & N.S & 0.05 \\
\hline
\end{tabular}

Note: T1,T2,T3 Organic Selenium treatments with a concentration 0.3.0.6.0.9 mg/kg feed, T4, T5,T6 inorganic Selenium treatments with a concentration of $0.3,0.6 .0 .9 \mathrm{mg} / \mathrm{kg}$ feed, $\mathrm{T} 7 \mathrm{control}$ treatment without the addition of Selenium.

The different letters within one column indicate the presence of a significant difference $(P \leq 0.01)(P \leq 0.05)$.

N.S indicates that there are no significant differences within one column 
Table 3 Shows the effect of organic and inorganic Selenium on blood Hematocrit and Hemoglobin concentration, as the results indicated a high significant $(\mathrm{P} \leq 0.01)$ superiority for $\mathrm{T} 1, \mathrm{~T} 3$ and $\mathrm{T} 7$ treatments, which did not differ significantly from $\mathrm{T} 2$ and T4 on T5 , T6 at 21 days of age. Moreover, the results showed at 42 days, a high significant superiority for $\mathrm{T} 1, \mathrm{~T} 7$ on treatment $\mathrm{T} 3$, and inorganic Selenium treatments T4, T5 and T6, which did not differ significantly from $\mathrm{T} 2$, whereas T4 treatment was exceeded on T5 and T6, and T5 also exceeded on T6. While the results for the general average of the two readings showed a high significant $(\mathrm{P} \leq 0.01)$ superiority for $\mathrm{T} 1$ and $\mathrm{T} 7$ over the rest of the treatments, as well as, high significant ( $\mathrm{P}$ $\leq 0.01$ ) superiority of $\mathrm{T} 2, \mathrm{~T} 3$ and $\mathrm{T} 4$ treatments compared to T5 and T6. The cause of poisoning in inorganic Selenium treatments and the results of the tests generally indicate that may be caused the decreases in packed cell volume (PCV) and the hemoglobin $(\mathrm{Hb})$ values, as (44) pointed out that the general average of blood Hematocrit and Hemoglobin for broiler Ross 308 in normal conditions was 30.73. The reason may be due to the high temperatures that led to increased water consumption by birds and the occurrence of hemodilution. Thus, a decrease in erythrocytes, which led to a decrease in blood Hematocrit and Hemoglobin values (7). The study results were not agree with what (39) findings, when adding organic Selenium at 0.15 and $0.3 \mathrm{mg} / \mathrm{kg}$ diet, it increased the average of blood Hematocrit and Hemoglobin, as well as, an improving of cells and immune blood pictures compared to organic Selenium treatments, which are consistent with(33) results, while there are no differences in the erythrocytes number and blood Hematocrit and Hemoglobin concentration, when using Selenium as a dietary supplement compared to the control treatment $(14,31)$

Table 3. Effect of adding different levels of organic Selenium (Selenomethionin) and inorganic (sodium selenite) to the diet in the blood Hematocrit $(\%)$ and Hemoglobin $(\mathbf{m g} / 100 \mathrm{ml})$ at the age of 21 and 42 days and the general rate of broiler diet rearing at a high temperatures

(general average \pm standard error).

\begin{tabular}{|c|c|c|c|c|c|c|}
\hline Treatments & \multicolumn{3}{|c|}{ PCV } & \multicolumn{3}{|c|}{$\mathbf{H b}$} \\
\hline & 21 & 42 & $1-42$ & 21 & 42 & $1-42$ \\
\hline T1 & $27.14 \pm^{\mathrm{A}} \mathbf{0 . 8 6}$ & $29.93 \pm^{\mathrm{A}} \mathbf{0 . 4 3}$ & $28.54 \pm^{\mathrm{A}} \mathbf{0 . 4 9}$ & $9.05 \pm^{\mathrm{A}} 0.29$ & $9.98 \pm^{\mathrm{A}} 0.14$ & $9.51 \pm^{A} 0.16$ \\
\hline T2 & $25.33 \pm^{\mathrm{AB}} 0.80$ & $28.50 \pm^{\mathrm{AB}} 0.84$ & $26.63 \pm^{\mathrm{B}} 0.62$ & $8.44 \pm^{\mathrm{AB}} \mathbf{0 . 2 7}$ & $9.50 \pm^{\mathrm{AB}} 0.28$ & $8.88 \pm^{\mathrm{B}} 0.21$ \\
\hline T3 & $25.93 \pm^{\mathrm{A}} 0.37$ & $27.38 \pm^{\mathrm{B}} 0.72$ & $26.61 \pm^{\mathrm{B}} \mathbf{0 . 5 0}$ & $8.64 \pm{ }^{\mathrm{A}} \mathbf{0 . 1 2}$ & $9.13 \pm \pm^{B} 0.24$ & $8.87 \pm^{\mathrm{B}} 0.17$ \\
\hline T4 & $25.36 \pm^{\mathrm{AB}} 1.21$ & $24.56 \pm^{\mathrm{C}} 0.26$ & $24.93 \pm^{\mathrm{B}} 0.64$ & $8.45 \pm^{\mathrm{AB}} 0.40$ & $8.19 \pm{ }^{\mathrm{C}} 0.09$ & $8.31 \pm^{\mathrm{B}} 0.21$ \\
\hline T5 & $22.07 \pm{ }^{C_{1}} 1.43$ & $22.44 \pm^{\mathrm{D}} \mathbf{0 . 5 5}$ & $22.25 \pm^{\mathrm{C}} \mathbf{0 . 5 8}$ & $7.36 \pm^{\mathrm{C}} \mathbf{0 . 4 8}$ & $7.48 \pm \pm^{\mathrm{D}} \mathbf{0 . 1 8}$ & $7.42 \pm^{\mathrm{C}} 0.19$ \\
\hline T6 & $22.40 \pm^{\mathrm{BC}} 0.48$ & $20.00 \pm{ }^{\mathrm{E}} \mathbf{0 . 3 7}$ & $21.35 \pm^{\mathrm{C}} 0.17$ & $7.47 \pm^{\mathrm{BC}} \mathbf{0 . 1 6}$ & $6.67 \pm \pm^{\mathrm{E}} \mathbf{0 . 1 2}$ & $7.12 \pm{ }^{\mathrm{C}} \mathbf{0 . 0 6}$ \\
\hline T7 & $27.92 \pm{ }^{\mathrm{A}} 1.42$ & $29.00 \pm{ }^{\mathrm{A}} \mathbf{0 . 4 6}$ & $28.54 \pm^{\mathrm{A}} \mathbf{0 . 7 7}$ & $9.31 \pm{ }^{\mathrm{A}} \mathbf{0 . 4 7}$ & $9.67 \pm \pm^{\mathrm{A}} \mathbf{0 . 1 5}$ & $9.51 \pm^{A} 0.26$ \\
\hline $\begin{array}{c}\text { Significant } \\
\text { level }\end{array}$ & 0.01 & 0.01 & 0.01 & 0.01 & 0.01 & 0.01 \\
\hline
\end{tabular}

Note: T1,T2,T3 Organic Selenium treatments with a concentration 0.3.0.6.0.9 mg/kg feed, T4, T5,T6 inorganic Selenium treatments with a concentration of $0.3,0.6 .0 .9 \mathrm{mg} / \mathrm{kg}$ feed, $\mathrm{T} 7$ control treatment without the addition of Selenium.

The different letters within one column indicate the presence of a significant differences $(\mathrm{P} \leq \mathbf{0 . 0 1})$.

The results in Table 4 show that there are no significant differences between the sources of Selenium and its levels in the broiler diet at a concentration of glucose and cholesterol in the blood plasma at 21 and 42 days of age, as well as the general average of two readings. Results showed that it is not possible to ignore the influence of Selenium in lowering cholesterol and glucose levels at 42 days of age compared to their 21-days of age levels in all treatments. Although, there are no significant differences, this may be due to the role of Selenium as an antioxidant and its role in curbing free radicals as well as, the addition of Selenium in the diet has led to increasing the Selenium concentration within the body. Thus, it improves antioxidant defenses and protects cellular membranes from oxidation and damage and works to increase the efficiency of antioxidant activities. Furthermore the effect of Selenium on thyroid activity and the conversion of thyroxin (T4) to Triiodothyronine (T3) was the most effective in increasing metabolism and the metabolic rate within the body, which may explain the low level of glucose ( 18 ). ( 41 ) stated that the thyroid gland has a directly related to cholesterol metabolism, as the high activity of 
thyroid hormones leads to reduce cholesterol levels.

Table (4) The effect of adding different levels of organic Selenium (Selenomethionin) and inorganic (sodium selenite) to the diet in the glucose concentration ( $\mathrm{mg} / \mathrm{dl})$ and cholesterol concentration $(\mathrm{mg} / \mathrm{dl})$ at 21 and 42 days of age and the general average of broiler reared at a high temperatures (general average \pm standard error).

\begin{tabular}{|c|c|c|c|c|c|c|}
\hline \multirow[t]{2}{*}{ Treatments } & \multicolumn{3}{|c|}{ Glucose concentration } & \multicolumn{3}{|c|}{ Cholesterol concentration } \\
\hline & 21 & 42 & $1-42$ & 21 & 42 & $1-42$ \\
\hline T1 & $259.80 \pm 5.68$ & $228.60 \pm 6.23$ & $244.20 \pm 5.25$ & $130.00 \pm 9.15$ & $121.40 \pm 8.13$ & $125.70 \pm 6.35$ \\
\hline $\mathbf{T} 2$ & $259.80 \pm 5.68$ & $228.00 \pm 5.51$ & $243.90 \pm 4.32$ & $123.40 \pm 5.29$ & $130.40 \pm 3.43$ & $126.90 \pm 3.33$ \\
\hline T3 & $262.60 \pm 5.57$ & $212.60 \pm 15.85$ & $237.60 \pm 9.37$ & $127.40 \pm 9.75$ & $112.80 \pm 8.30$ & $120.10 \pm 4.69$ \\
\hline T4 & $261.60 \pm 5.66$ & $221.60 \pm 15.45$ & $241.60 \pm 7.70$ & $135.20 \pm 7.07$ & $121.20 \pm 6.74$ & $128.20 \pm 3.70$ \\
\hline T5 & $267.40 \pm 6.52$ & $248.00 \pm 16.86$ & $257.70 \pm 8.93$ & $146.00 \pm 7.19$ & $133.60 \pm 8.72$ & $139.80 \pm 7.38$ \\
\hline T6 & $255.20 \pm 8.30$ & $219.00 \pm 17.08$ & $237.10 \pm 9.65$ & $144.00 \pm 11.10$ & $132.80 \pm 15.42$ & $138.40 \pm 10.07$ \\
\hline T7 & $263.00 \pm 3.94$ & $22.07 \pm 204.20$ & $233.60 \pm 9.85$ & $124.00 \pm 4.84$ & $129.60 \pm 8.48$ & $126.80 \pm 4.23$ \\
\hline Significant level & N.S & N.S & N.S & N.S & N.S & N.S \\
\hline
\end{tabular}

Note: T1,T2,T3 Organic Selenium treatments with a concentration 0.3.0.6.0.9 mg/kg feed, T4, T5,T6 inorganic Selenium treatments with a concentration of $0.3,0.6 .0 .9 \mathrm{mg} / \mathrm{kg}$ feed, $\mathrm{T} 7$ control treatment without the addition of Selenium.

N.S indicate that there is no significant differences within one column.

\section{REFERENCES}

1. Al-Hassani, D.H.1991. Effect of heat stress on some physiological characteristics of Iraqi indigenous chickens. Iraqi Journal of Agricultural Sciences. 22(2):77-82.

2. Al-Hassani, D.H. and I.A.Abdul-Hassan. 1999.Increase of body temperature and its relation with subsequent heat resistance to heat stress in male chickens. Iraqi Journal of Agricultural Sciences..30 (1):667-672.

3. Al-Hassani, D.H.and.M.S.Al-Jebouri,1988. Heat tolerance of Iraqi indigenous chickens. XV1ll World's poultry congress Nagoya, Japan $686-688$.

4. Al-Hassani, D.H. and A.Y.AlNaib.1991.Effect of lighting and feeding regimes on some productive parameters in laying hens during hot summer in Iraq. Iraqi Journal of Agricultural Sciences. 22 (2): 8388.

5. Al-Hassani, D.H. and A.Y.AlNaib.1993.Egg quality as influenced by lighting and feeding regimes of laying hens during hot summer in Iraq. Iraqi Journal of Agricultural Sciences Iraq. 22(2): 74-79.

6. Al-Hassani, D.H. and D.K. Ibrahim .1994. The feasibility of short - term fasting for the improvement of thermal resistance of broiler exposed to heat stress. Iraqi Journal of Agricultural Sciences.25 (2): 85-90.

7. Al-Hassani, D. H, K. M. Abdul-Latif and B. G. Al-Kateeb. 2002 . Effect of adding different levels of vitamin $\mathrm{E}$ with drinking water on some blood characteristics of broiler.
Iraqi Journal of Agricultural Sciences. Sci. 33. (3).

8. Al-Hassani, D.H. and A.Y., AlShukri.2011.Effect of using different concentrations of betaine on some productive traits of broiler reared under high temperature. Kufa J. for Agricultural Science. 3 (1): 164171.

9. Al-Hassani, D.H. and A.Y., Al-Shukri. 2016. Comparative efficacy of different supplements with drinking water used to alleviate body temperature of heat-stressed broiler chickens. The Iraqi Journal of Agricultural Sciences, 47(Special Issue):1218.

10. Al-Shukri. A.Y., and D. H. AlHassani,2012. Effect of betaine supplemented with drinking water on water intake pattern of broiler chickens exposed to heat stress .Journal of Tikrit University for Agricultural Science. 12.( 2): 107-115.

11. Al-Rubaye, H . I .2015. Comparison of Adding Organic and Inorganic Selenium to the Diet on Reproductive, Productive and Physiological Performance of Females and Males of Lomann Brown Laying Hens. Ph.D. Dissevtation. College of Agriculture University of Baghdad.

12. Arad, Z. and J. Marder. 1982. Comparative thermoregulation of four breed of fowl (Gallus domesticus), exposes to a gradual increase of ambient temperatures. Comp. Biochem. Phsiol., 72A: 179-184. 
13.Archer, R. K. 1965. Hematological technique for Use on Animal. Blackwell Scientific Publication, Oxford.

14.Boostani, A., A. Asghar Sadeghi, S., Naser Mousavi, M. , Chamani and N. Kashan. 2015. The effects of organic, inorganic, and nanoselenium on blood attributes in broiler chickens exposed to oxidative stress. Acta Scientiae Veterinariae, 43:1-6.

15.Borges, S.A., S.A, A.V. Fischer da silva, A. Majorka, D.M. Hooge and K.R. Cummings. 2004. Physiological responses of broiler chickens to heat stress and dietary Electrolyte Balance (sodium plus potassium Minus chloride , Milliequivalants per Kilogram) poultry Sci. 83 : 1551- 1558.

16.Bottje, W., N.R. Pumford, C. , OjanoDirain, M. , Iqbal, and K. Lassiter. 2006. Feed efficiency and mitochondrial function. Poultry science, 85(1) : 8-14.

17.Campbell, T. W. 1995. Avian Hematology and Cytology. Iowa State, University Press, Ames, Iowa.

18.Choupani, M., P.Z., Moghadam, H.R., Kelidari and S. Ghazi. 2014. Influence of dietary selenium sources on thyroid hormone activation, tissue selenium distribution and antioxidant enzymes status in broiler chickens. DAMA International, $3: 281297$.

19.Diplock, A.T., J.L., Charuleux, G., CrozierWilli, F.J., Kok, C., Rice- Evans, M., Roberfroid, W., Stahl and J. Vina-Ribes. 1998. Functional food science and defence against reactive oxidative species. British Journal of Nutrition, 80(S1) : S77-S112.

20.Duncan, D. B. 1955. Multiple Ranges and Multiple F- test. Biometrics, 11: 1-24.

21.El Boushy, A.R. and A.L. Van Marle. 1978. The effect of climate on poultry physiology in tropics and their improvement. World's Poultry Science Journal, 34(3) : 155171.

22.Fan, C., Yu, B. and D. Chen. 2009. Effects of different sources and levels of selenium on performance, thyroid function and antioxidant status in stressed broiler chickens. Int J Poult Sci, 8(6) : 583-587.

23.Fisinin, V.I., T.T. Papazyan and P.F. Surai. 2009. Producing selenium-enriched eggs and meat to improve the selenium status of the general population. Critical Reviews in Biotechnology, 29(1) :18-28.
24.Habeeb G.R., D.H., Al-Hassani and I.H. Ismail . 2004. Effect of enzymes supplementation on some productive traits of broiler reared under hot climate. Iraqi. J.Agri. Sci. 35(1):141-144.

25.Ibrahim D.K. and D.H. AlHassani.1997.Effect of acclimation to heat stress during early age and second critical period of adrenal development on broiler performance reared later under high temperature Iraqi.J.Agri.Sci,28(1):221-228.

26.Ibrahim D.K., D.H., Al-Hassani and A.S. Ahmad. 1999. Effect of different levels of dietary vegetable oil supplemented to rations during the hot period of the day on performance of male broiler. Iraqi.J.Agri.Sci.30(1):333-392.

27.Markovic, R., J., Ciric, A., Drljacic, D., Sefer, I., Jovanovic, D., Jovanovic, S., Milanovic, D., Trbovic, S., Radulovic, Baltic, M.Z. and M. Starcevic. 2018. The effects of dietary Selenium- yeast level on glutathione peroxidase activity, tissue Selenium content, growth performance, and carcass and meat quality of broilers. Poultry Science, 97(8), 2861-2870.

28.Mohamed, H.S., Y.S., Rizk, A.E., ElSlamony, A.A.M. Soliman and A.F. Ibrahim 2016. study the relationship between selenium And heat shock proteins under heat stress for local Sinai Chickns strain . Egyptian Poultry Science Journal, 36(1).

29.National Research Council (NRC). 1994. Nutrient Requirements of Poultry. 9th rev. ed. National Academy Press, Washington, D. C., U.S.A.

30.Nawab, A., F., Ibtisham, G., Li, B., Kieser, J., Wu, W., Liu, Y., Zhao, Y., Nawab, K., Li, M., Xiao and L. An . 2018. Heat stress in poultry production; Mitigation strategies to overcome the future challenges facing the global poultry industry. Journal of thermal biology.

31.Osman, A. M. R., H. M., Abdel-Wahed and M. S. Ragab. 2010. Effects of supplementing laying hens diets with organic selenium on egg production, egg quality, fertility and hatchability. Egypt. Poultry Sci., 30: 893-915. 32.Osti, R., D., Bhattarai and D. Zhou. 2017. Climatic variation: effects on stress levels, feed intake, and bodyweight of broilers. 
Brazilian Journal of Poultry Science, 19(3) : 489- 496.

33.Raduta, A., D. , Curca and C. Constantinescu . 2011. Variation of some hematological indicators, hematological indices and white blood cell count in chicks fed with organic selenium supplemented fodder. Scientific Works-University of Agronomical Sciences and Veterinary Medicine, Bucharest Series C, Veterinary Medicine, 57(3): 39-45.

34.Rao, S. R., B., Prakash, M., Raju, A., Panda, R., Kumari and E. P. K. Reddy. 2016. Effect of supplementing organic forms of zinc, selenium and chromium on performance, antioxidant and immune responses in broiler chicken reared in tropical summer. Biological trace element research, 172: 511-520.

35.Rotruck, J. T., A. L. Pope, H. E. Ganther, A. B. Swanson, D. G. Hafeman and W. G. Hoekstra. 1973. Selenium: biochemical role as a component of glutathione peroxidase. Science. 179:588- 590.

36.Sahin, K. and O. Kucuk. 2003. Heat stress and dietary vitamin supplementation of poultry diets. In Nutrition Abstracts and Reviews. Series B, Livestock Feeds and Feeding (Vol. 73 (7). CAB International.

37.Sahin, K., 2015. Modulation of NF- $\kappa B$ and Nrf2 pathways by lycopene supplementation in heat-stressed poultry. World's Poultry Science Journal, 71(2) : 271-284.

38.SAS. 2012. Statistical Analysis System, User's Guide. Statistical. Version $9.1^{\text {th }}$ ed. SAS. Inst. Inc. Cary. N.C. USA.

39.Selim, N.A., N.L., Radwan, S.F., Youssef, T.S. , Eldin and S.A. Elwafa. 2015. Effect of inclusion inorganic, organic or nano selenium forms in broiler diets on: 1growth performance, carcass and meat characteristics. International Journal of Poultry Science, 14(3) : 135-143.
40.Sevcikova, S., M., Skrivan, G.,Dlouha and M. Koucky. 2006. The effect of selenium source on the performance and meat quality of broiler chickens. Czech Journal of Animal Science, 51(10) : 449-457.

41.Sturkie, P. D. 2000. Avian Physiology. 5 th ed. New York, Heiderberg, Barlin.

42.Surai, P.F., 2006. Selenium in nutrition and health Nottingham: Nottingham university press. 974

43.Surai, P.F. and I.I. Kochish. 2018. Nutritional modulation of the antioxidant capacities in poultry: The case of selenium. Poultry science.

44.Talebi, A., S., Asri-Rezaei, R., Rozeh-Chai and R. Sahraei. 2005. Comparative studies on haematological values of broiler strains (Ross, Cobb, Arbor-acres and Arian). Int. J. Poultry Sci, 4 (80) : 573-579.

45.Taouis, M., V., De Basilio, S., MignonGrasteau, S., Crochet, C., Bouchot, K., Bigot, A., Collin, and M. Picard . 2002. Early- age thermal conditioning reduces uncoupling protein messenger RNA expression in pectoral muscle of broiler chicks at seven days of age. Poultry Science, 81(11) : 1640.

46.Visha, P., K., Nanjappan, P., Selvaraj, S., Jayachandran, V. and Thavasiappan. 2017. Influence of Dietary Nanoselenium Supplementation on the Meat Characteristics of

Broiler Chickens.

47.Yalcin , S., S.,Ozkan ,L., Turkmut and P. B. Siegel . 2001. Responses to heat stress in commercial and local broiler stocks . 1Performance traits. Brit. Poultry Sci. 42 (2) : $149-152$.

48.Yoon, I., T.M., Werner, and J.M. Butler. 2007. Effect of source and concentration of selenium on growth performance and selenium retention in broiler chickens. Poultry Sci. 86(4) : 727-730. 